\title{
Short Communication: In vitro antibacterial activity of essential oils from twelve aromatic plants from East Kalimantan, Indonesia
}

\author{
HARLINDA KUSPRADINI ${ }^{1, \boldsymbol{v}}$, AGMI SINTA PUTRI ${ }^{1}$, SAAT EGRA ${ }^{2}$, YANTI $^{3}$ \\ ${ }^{1}$ Faculty of Forestry, Universitas Mulawarman. Jl. Penajam, Kampus Gunung Kelua, Samarinda 75116, East Kalimantan, Indonesia. \\ Tel.: +62-541-735089, `email: hkuspradini@ fahutan.unmul.ac.id, alinkuspra@gmail.com \\ ${ }^{2}$ Universitas Borneo Tarakan. Jl. Amal Lama No. 1, Tarakan Timur, Tarakan 77115, North Kalimantan, Indonesia \\ ${ }^{3}$ Faculty of Biotechnology, Universitas Katolik Atmajaya Jakarta. J1. Jenderal Sudirman 51, Jakarta 12930, Indonesia.
}

Manuscript received: 11 May 2019. Revision accepted: 29 June 2019

\begin{abstract}
Kuspradini H, Putri AS, Egra S, Yanti. 2019. Short Communication: In vitro antibacterial activity of essential oils from twelve aromatic plants from East Kalimantan, Indonesia. Biodiversitas 20: 2039-2042. In the aim of this works was to investigate the antibacterial activity of twelve essential oils against Streptococcus mutans and Streptococcus sobrinus, oral pathogen causing dental caries. The essential oils were collected by a steam distillation method. Refractive index was measured by using a refractometer. The antibacterial activity of essential oils was determined using an agar well diffusion method. The yields of essential oils varied with the plant species. The steam distillation yielded clear to yellowish essential oils. Refractive indexes of oil were found to be in the range of 1.344 to 1.500 . Syzigium sp. appeared to be more abundant in oil (1.54\%) than the other plant species, while $C$. odorata was poorer $(0.04 \%)$. All of the essential oils tested showed a varied level of inhibition zone $(0-53.65 \mathrm{~mm})$ against $S$. mutans and $S$. sobrinus. The oil from leaves of Cymbopogon citratus had the highest activity against $S$. sobrinus and $S$. mutans (53.15 and $52.85 \mathrm{~mm}$, respectively). On the other hand, the Magnolia $x$ alba oil showed the lowest activity against S. mutans and S. sobrinus $(10.50$ and $11.65 \mathrm{~mm}$, respectively). The research results demonstrated that the essential oil in this study has the potency for development of dental health products for preventing and treating oral infections.
\end{abstract}

Keywords: Essential oils, Streptococcus mutans, Streptococcus sobrinus, East Kalimantan

\section{INTRODUCTION}

Essential oil is one of the natural ingredients that can be used to treat bacterial infections. Essential oils from several plants were able to control the growth of microorganisms causing skin infections, dental caries, and food spoilage. Essential oils have a potential application in the management of dental caries (Lang and Buchbauer 2012; Lobo et al. 2014). Several oral products have incorporated essential oil-derived antimicrobials such as eucalyptus, lavandula, and rosmarinus (Allaker et al. 2009). People have traditionally used essential oils such as calamus, citronella, clove, eucalyptus, lemongrass, lime, cananga (ylang-ylang), piper for various purposes in different parts of the world.

Acorus calamus has many biological activities as insecticidal, antifungal, antibacterial properties (Phongpaichit et al. 2005). The essential oils of A. calamus have been found to possess an antibacterial activity (Şerban et al. 2015; Kasture et al. 2015). Various ethnomedicinal and ethnobotanical uses have been ascribed to the rhizomes of the plant (Manikandan et al. 2010). Cloves (Syzygium aromaticum (Linn.) (Syn. Eugenia aromatica) have been used by humans for medicinal applications to alleviate toothache (Chaieb et al. 2007; Hema et al. 2010; Duke 1985). In Thailand and Indonesia, Zingiber cassumunar has been used as traditional medicine (Waranee et al. 2012). In
Indonesia, Z. cassumunar has been traditionally used to relieve colic in children (Ong 2008). The young shoots of Macaranga triloba, $M$. pruinosa, and $M$. gigantea are used to treat fungal infections, while decoctions of their leaves are known to treat stomach aches (Fiala et al. 1989; Grosvenor et al. 1995). Cananga odorata (ylang-ylang) oil can be found in various cosmetic and households products such as the massage oils, moisturizing creams, perfumes, and even scented candles, and also safety as a food ingredient. Ylang-ylang essential oils have been investigated covering the antibacterial, antifungal, amebicidal, and cytotoxic activities (Hern et al. 2015; Burdock and Carabin 2008; Saedi and Crawford 2006). Eucalyptus deglupta is used to a limited extent for firewood and charcoal. The genus Eucalyptus essential oils are widely used all over the word as spices, flavors, perfumes industrial raw materials, and pharmaceutical (Dellacassa et al. 1990; Boland et al. 1991). The essential oil of Citrus hystrix has been used as flavor and fragrance agents, as well as in perfumery and medicinal preparation (Doreen et al. 2011). Lime oil from Indonesia contains abundant bioactive compounds and shows antimicrobial and antioxidant activity (Lawrence et al. 1971).

Even though, there are several studies on antimicrobial activity of these plant species in Indonesia, studies on the essential oils of different species from a specific part of the plant in East Kalimantan have not been extensively 
conducted. This study was done to investigate and compare the antibacterial activity of the essential oil derived plants locally available in East Kalimantan against oral bacteria and to search for the most effective essential oil from these plants.

\section{MATERIALS AND METHODS}

\section{Study area}

Leaves of aromatic plants were collected from Samarinda, East Kalimantan. Magnolia $x$ alba, Acorus calamus, Zingiber cassumunar, Piper odorata, Syzygium aromaticum, Eucalyptus deglupta, Macaranga gigantea, Cananga odorata, Syzygium sp., Citrus hystrix, Cymbopogon nardus, Cymbopogon citratus were the selected aromatic plants.

\section{Procedures}

\section{Steam distillation method}

The essential oils extraction process was conducted using the steam distillation method (Kuspradini et al. 2016). The result of the steam distillation process was two layers solution containing oil and water. The oils were collected and separated using the separatory funnel. $\mathrm{Na}_{2} \mathrm{SO}_{4}$ was added to the oils and incubated for 24 hours to get pure essential oils. The volume of oils was presented according to the yield.

\section{Antibacterial assay}

The antibacterial activity was assayed by the agar diffusion method (Kuspradini et al. 2016) and replicated two times. Streptococcus mutans and Streptococcus sobrinus were used in this study. Sterilization of all used materials was conducted by using an autoclave at $121^{\circ} \mathrm{C}$ for 15 minutes. Bacteria were cultured in sterile nutrient agar (NA) and incubated at $37^{\circ} \mathrm{C}$ for 24 hours. $25 \mu \mathrm{l}$ of the bacterial suspension was then spread all over the surface of solid media plates three times by sterile swab. After that, wells were made by using a sterile cork borer of $6 \mathrm{~mm}$ in diameter. Twenty microliters of the pure essential oils were added into the wells, then were incubated at $37^{\circ} \mathrm{C}$ for $18-24$ hours. In this study, Chlorhexidine was used as an antibiotic for positive control at the concentration of $10 \mu \mathrm{g}$ well $^{-1}$, and acetone was used as a negative control. The negative control showed no inhibitions in preliminary studies. After incubation, the plates were observed for the formation of a clear inhibition zone around the well, indicating the presence of antibacterial activity. The Inhibition Zone (IZ) was determined by measuring the diameters of the inhibition zone around the well (in mm, taken with a ruler), and the Activity Index (AI) was calculated using the formula below:

Activity Index $=$ (Inhibition Zone of essential oil sample/Inhibition Zone of antibiotic)

\section{Data analysis}

The results of steam distillation, including yields and color of oil, were presented in Tables and Figure. The antibacterial assay was made in duplicates, and the data were reported as mean $\pm \mathrm{SD}$ for $(\mathrm{n}=1 \times 2)$ presented in Tables 1, 2, and 3 .

\section{RESULTS AND DISCUSSION}

All essential oils were obtained from steam distillation process. The yields of essential oils varied with plant species. The steam distillation yielded clear and yellowish essential oils (Figure 1). Refractive indexes of oil were found to be in the range of 1.340 to 1.500 . The results of the yields and refractive indexes are presented in Table 1. Syzigium sp. appeared to be more abundant in oil (1.54\%) than the other plant species, while $C$. odorata was poorer $(0.04 \%)$. The Syzygium species of the family Myrtaceae are well known for their aromatic nature. In this study, several species of the family Myrtaceae had a higher yield (0.22-1.54\%) compared to that obtained by Rameshkumar et al. (2015) and Muthumperumal et al. (2016). The leaf essential oil yield was between $0.10-0.33 \%$. Our results indicated that the species of the family Myrtaceae in East Kalimantan had oil yields higher than previously reported.

In the distillation process, filling of the material into the kettle should be arranged in such a way that steam can penetrate and be flattened in the material so that it would produce more yield of oil (Guenther 2006). The refractive index of Zingiber oil (1.500) was higher than the other oils in this study, while the lowest was Magnolia oil (1.340). Sukatta et al. (2009) reported that the range of refractive indexes of $Z$. cassumunar rizhome oil was between 1.51691.5386. The refractive index value can be known from the presence of water contained in oil; the higher the water content in oil, the smaller the refractive index. Therefore, higher refractive index values in essential oils are better than lower ones (Sastrohamidjojo 2004).

Two bacteria were investigated for their susceptibility against the essential oils. Although the inhibitory zone of the sample has a lower value than the positive control, it does not mean that the sample has no antimicrobial activity. The clear zones appear on all samples tested in different size (pictures not shown). The clear zone or inhibition zone is the area around the well-containing sample where the bacterial growth is not visible. Tables 2 and 3 showed that all of the essential oil samples tested in this study had the potency to suppress the growth of $S$. mutans and S. sobrinus. The inhibition zone range of the 12 essential oils in this study against $S$. mutans and $S$. sobrinus were $10.50-53.65 \mathrm{~mm}$ and $11.65-53.15 \mathrm{~mm}$, respectively. 

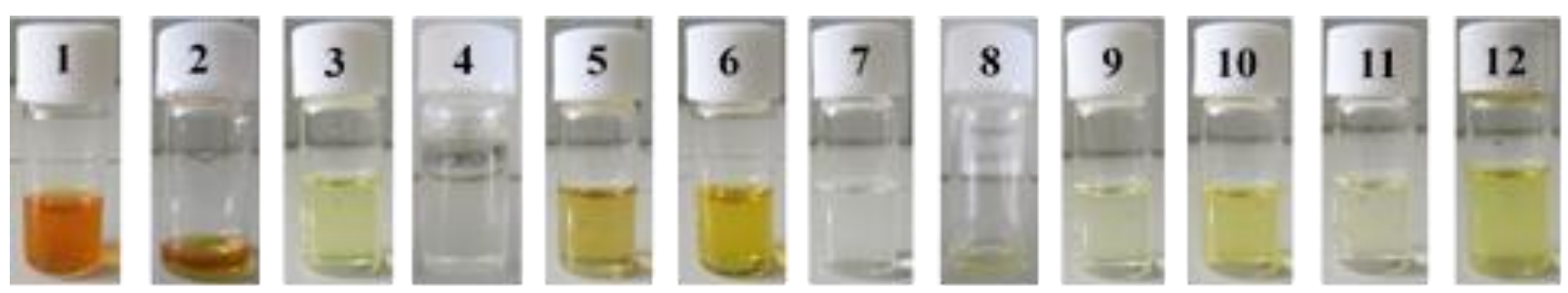

Figure 1. Varying color of essential oils extracted from various plant species: (1) M. alba, (2) A. calamus, (3) Z. cassumunar, (4) P. odorata, (5) S. aromaticum, (6) E. deglupta, (7) M. gigantea, (8) C. odorata, (9) Syzygium sp., (10) C. histrix, (11) C. nardus, (12) C. citrates.

Table 1. The plant species, family, oil yield, and refractive index of extracted oils obtained in the present study.

\begin{tabular}{|c|c|c|c|c|}
\hline Plant species & Family & Yield \%) & Color & Refractive index \\
\hline Magnolia x alba & Magnoliaceae & 0.28 & Orange & 1.344 \\
\hline Acorus calamus & Acoraceae & 0.35 & Brownish Yellow & 1.482 \\
\hline Zingiber cassumunar & Zingiberaceae & 0.25 & Yellow & 1.500 \\
\hline Piper odorata & Piperaceae & 0.06 & Colorless & 1.492 \\
\hline Syzygium aromaticum & Myrtaceae & 0.22 & Yellow & 1.459 \\
\hline Eucalyptus deglupta & Myrtaceae & 0.40 & Yellow & 1.485 \\
\hline Macaranga gigantea & Euphorbiaceae & 0.34 & Colorless & 1.369 \\
\hline Cananga odorata & Annonaceae & 0.04 & Pale Yellow & 1.496 \\
\hline Syzygium sp. & Myrtaceae & 1.54 & Pale Yellow & 1.485 \\
\hline Citrus hystrix & Rutaceae & 1.26 & Yellow & 1.452 \\
\hline Cymbopogon nardus & Poaceae & 0.26 & Pale Yellow & 1.367 \\
\hline Cymbopogon citratus & Poaceae & 0.46 & Yellow & 1.385 \\
\hline
\end{tabular}

Table 2. Inhibition zone and activity indices of pure essential oils against $S$. mutans

\begin{tabular}{|c|c|c|c|}
\hline \multirow{2}{*}{$\begin{array}{l}\text { Plant species } \\
\text { (sample) }\end{array}$} & \multicolumn{2}{|c|}{ Inhibition zone (mm) } & \multirow{2}{*}{$\begin{array}{l}\text { Activity } \\
\text { index }\end{array}$} \\
\hline & Sample & $\begin{array}{c}\text { Positive } \\
\text { control *) }\end{array}$ & \\
\hline Magnolia x alba & $10.50 \pm 0.28$ & & $0.63 \pm 0.02$ \\
\hline Acorus calamus & $14.65 \pm 0.49$ & & $0.88 \pm 0.03$ \\
\hline Zingiber cassumunar & $18.65 \pm 6.15$ & & $1.12 \pm 0.37$ \\
\hline Piper odorata & $20.85 \pm 5.87$ & & $1.25 \pm 0.35$ \\
\hline Syzigium aromaticum & $22.15 \pm 1.20$ & $16.70 \pm 11.8$ & $1.33 \pm 0.07$ \\
\hline Eucalyptus deglupta & $23.35 \pm 0.49$ & & $1.40 \pm 0.03$ \\
\hline Macaranga gigantea & $23.65 \pm 0.92$ & & $1.42 \pm 0.06$ \\
\hline Cananga odorata & $43.50 \pm 9.19$ & & $2.60 \pm 0.55$ \\
\hline Syzygium sp. & $50.85 \pm 1.20$ & & $3.04 \pm 0.07$ \\
\hline Citrus hystrix & $51.70 \pm 0.00$ & & $3.10 \pm 0.00$ \\
\hline Cymbopogon nardus & $52.15 \pm 0.21$ & & $3.12 \pm 0.01$ \\
\hline Cymbopogon citratus & $52.85 \pm 1.63$ & & $3.16 \pm 0.10$ \\
\hline
\end{tabular}

* Chlorhexidine $\left(10 \mu \mathrm{g} \mathrm{ml}^{-1}\right)$ was used as a positive control

Measurement of the activity index was necessary to estimate whether the potential antimicrobial activity comparable to a positive control (antibiotic standard). Samples that have an activity index value of 1.00 mean the activity is the same as a positive control. Several essential oils in this study have an activity index higher than one, indicating that these oils exhibited higher antibacterial activity against $S$. mutans and $S$. sobrinus than the chlorhexidine (positive control) which is commonly used for antiseptic and dental setting.
Table 3. Inhibition zone and activity indices of pure essential oils against $S$. sobrinus

\begin{tabular}{|c|c|c|c|}
\hline \multirow[b]{2}{*}{$\begin{array}{l}\text { Plant species } \\
\text { (sample) }\end{array}$} & \multicolumn{2}{|c|}{ Inhibition zone (mm) } & \multirow[b]{2}{*}{$\begin{array}{l}\text { Activity } \\
\text { index }\end{array}$} \\
\hline & Sample & $\begin{array}{c}\text { Positive } \\
\text { control *) }\end{array}$ & \\
\hline Magnolia x alba & $11.65 \pm 0.49$ & & $0.66 \pm 0.03$ \\
\hline Macaranga gigantea & $13.50 \pm 0.71$ & & $0.76 \pm 0.04$ \\
\hline Acorus calamus & $17.80 \pm 2.12$ & & $1.01 \pm 0.12$ \\
\hline Piper odorata & $18.35 \pm 0.92$ & $7.70 \pm 0.00$ & $1.04 \pm 0.05$ \\
\hline Syzigium aromaticum & $20.00 \pm 0.00$ & & $1.13 \pm 0.00$ \\
\hline Eucalyptus deglupta & $34.50 \pm 0.28$ & & $1.95 \pm 0.02$ \\
\hline Zingiber cassumunar & $47.65 \pm 7.57$ & & $2.69 \pm 0.43$ \\
\hline Syzygium sp. & $50.00 \pm 0.00$ & & $2.82 \pm 0.00$ \\
\hline Cananga odorata & $51.30 \pm 2.83$ & & $2.90 \pm 0.16$ \\
\hline Citrus hystrix & $52.35 \pm 0.49$ & & $2.96 \pm 0.03$ \\
\hline Cymbopogon nardus & $52.50 \pm 0.28$ & & $2.97 \pm 0.02$ \\
\hline Cymbopogon citratus & $53.15 \pm 0.21$ & & $3.00 \pm 0.01$ \\
\hline
\end{tabular}

In this study, Cymbopogon citratus oil showed the highest activity against $S$. mutans $(52.85 \pm 1.63 \mathrm{~mm})$ and also against $S$. sobrinus $(53.15 \pm 0.21)$. The activity indices of essential oils extracted from Z. cassumunar, P. odorata, S. aromaticum, E. deglupta, M. gigantea, C. odorata, Syzygium sp., C. hystrix, C. nardus, and C. citratus, against $S$. mutans were found to be more than one, while that of $A$. calamus, P. odorata, S. aromaticum, E. deglupta, $Z$. cassumunar, Syzygium sp., C. odorata, C. hystrix, $C$. nardus, and $C$. citratus were more than one against $S$. 
sobrinus. these results indicated that these oils are exhibiting higher antibacterial activity than the chlorhexidine (antibiotic) used against bacterial pathogens, causing dental caries.

In the global oral health, dental caries remains one of the most prevalent diseases in spite of significant improvements (Gemert-Schricks et al. 2008). The main bacterial species responsible for lactic acid production and dental caries are Streptococcus (S. sobrinus and S. mutans) and Lactobacillus species (Madigan et al. 2003). This study demonstrated that the essential oils inhibited $S$. mutans and $S$. sobrinus growth, but their effectiveness varied. Oladimeji et al. (2001) and Faleiro (2011) mentioned that the chemical composition of the essential oils is strongly connected to their antimicrobial activity, and therefore, related to their composition, configuration, amount and their possible interaction. The hydrophobicity of essential oils increased cell permeability and consequent leaking of cell constituents (Burt 2004).

Based on our findings, $C$. nardus and C. citratus were strongly affecting the growth inhibition of $S$. sobrinus. Geranial was identified as the most abundant compound in $C$. citratus while citronellal was in $C$. nardus (Oliveira et al. 2010). These compounds might be attributed to the antimicrobial activity since Geranial (trans-citral, citral A) can act as a bactericidal and fungicidal agent (Cristianne 2008).

In conclusion, this research showed the antibacterial potency of the twelve essential oils from East Kalimantan in dental hygiene. The pure essential oil $(20 \mu \mathrm{l})$ of $C$. odorata, Syzygium sp., C. hystrix, C. nardus, C. citratus, $Z$. cassumunar, P. odorata, S. aromaticum, E. deglupta could inhibit both of $S$. mutans and $S$. sobrinus better than chlorhexidine $(10 \mu \mathrm{g})$, while $M$. gigantea and A. calamus could inhibit better than chlorhexidine against one bacteria only: S. mutans and S. sobrinus, respectively. Future research is still needed to quantify the active phytochemical compounds.

\section{ACKNOWLEDGMENTS}

The authors gratefully acknowledge the Ministry of Education and Culture, Republic of Indonesia for the financial research support (Grant Number 36.i/H17.16/PG/2014) and members of Laboratory of Forest Products Chemistry, Faculty of Forestry, Mulawarman University, East Kalimantan, Indonesia.

\section{REFERENCES}

Allaker RP, Douglas CWI. 2009. Novel anti-microbial therapies for dental plaque-related diseases. Intl J Antimicrobial Agents, 33 (1): 8-13.

Boland DJ, Brophy JJ, House PN. 1991. Eucalyptus leaf oils, use, chemistry, distillation, and marketing. Inkata Press, Melbourne.

Burdock GA, Carabin IG. 2008. Safety assessment of Ylang-Ylang (Cananga spp.) as a food ingredient. Food and Chemical Toxicology 46 (2): 433-445.

Burt S. 2004. Essential oils: their antibacterial properties and potential applications in food-a review. Intl J Food Microbiol 94: 223-53.

Chaieb K, Hajlaoui H, Zmantar T, Nakbi KAB, Rouabhia M, Mahdouani K, Bakhrouf A. 2007. The chemical composition and biological activity of essential oil, Eugenia caryophyllata (Syzygium aromaticum
L. Myrtaceae): a short review. Phytother Res 21 (6): 501-506.

Cristianne D, Silva SG, Vanessa W, Elfrides ES. 2008. Antifungal activity of lemongrass oil and citral against Candida spp. Brazilian J Infect Dis 12: 63 .

Dellacassa E, Menedez P, Moyna P. 1990. Chemical composition of Eucalyptus essential oils grown in Uruguay. Flavour Fragrance J 5: 91-95.

Doreen SH, Rose LC, Suhaimi H, Mohamad H, Rozaini MZH, Tai M. 2011. Preliminary evaluation on the antibacterial activities of Citrus hystrix oil emulsions stabilized by tween 80 and span 80 . Intl J Pharm Pharmaceut Sci 3: 209-211.

Duke JT. 1985. Handbook of Medicinal Herbs. CRC Press, New York.

Fiala B, Maschwitz U, Tho YP, Helbig AJ. 1989. Studies on a South East Asian ant-plant association: protection of Macaranga trees by Crematogaster borneensis. Oecologia 79: 463-470.

Grosvenor PW, Supriono A, Gray DO. 1995. Medicinal plants from Riau province, Sumatra, Indonesia. Part 2: antibacterial and antifungal activity. J Ethnopharmacol 45 (2): 97-111.

Guenther E. 2006. The Essential Oils Vol I, Translated in Indonesian by S. Ketaren. UI Press, Jakarta. [Indonesian]

Hern TLT, Chan CK, Lee LH, Goh BH. 2015. Traditional uses, phytochemistry, and bioactivities of Cananga odorata (ylang-ylang). Evid-Based Compl Altern Med. DOI: 10.1155/2015/896314

Hema R, Kumaravel S, Sivasubramanian C. 2010. Study on the potentials of Syzygium aromaticum. Researcher 12: 1-4.

Kasture A, Patel S, Chauhan J, Krishnamurthy R. 2015. In vitro antimicrobial effect of essential oil from leaf and rhizome of various accessions of Acorus calamus Linn., and its phytochemical screening. European J Med Plants 9 (2): 1-13.

Kuspradini H, Putri AS, Sukaton E, Mitsunaga T. 2016. Bioactivity of essential oils from leaves of Dryobalanops lanceolata, Cinnamomum burmannii, Cananga odorata, and Scorodocarpus borneensis. Agric Agric Sci Procedia 9: 411-418.

Lang G, Buchbauer G. 2012. A review on recent research results (20082010) on essential oils as antimicrobials and antifungals. A review. Flavour Fragrance J 27: 13-39.

Lawrence BM, Hogg JW, Terhune SJ, Podimuang V. 1971. Constituents of the leaf and peel oils of Citrus hystrix D.C. Phytochemistry 10 (6): 1404-1405

Lobo PL, Fonteles CS, Marques LA, Jamacaru FV, Fonseca SG, de Carvalho CB, de Moraes ME. 2014. The efficacy of three formulations of Lippia sidoides Cham. essential oil in the reduction of salivary Streptococcus mutans in children with caries: A randomized, double-blind, controlled study. Phytomedicine 21: 1043-1047.

Manikandan SR, Sheela D, Srikumar R, Thangaraj R, Ayyappan R, Jegadeesh R, Hariprasath L. 2010. In-Vitro Antibacterial Activity of Aqueous and Ethanolic Extracts Of Acorus Calamus. Intl J Appl Biol Pharmaceut Technol 1 (3): 1072.

Muthumperumal C, Stalin N, Das AK, Swany PS. 2016. Chemical profiling of leaf essential oil, antioxidant, and antibacterial activity of Syzygium lanceolatum (Lam.) Wt. \& Arn. (Myrtaceae). Free Radic Antioxidants 6 (1): 13-22.

Oliveira MMM, Brugnera D, Cardoso MG, Alves E, Piccoli R. 2010. Disinfectant action of Cymbopogon sp. essential oils in different phases of biofilm formation by Listeria monocytogenes on stainless steel surface. Food Control 21: 549-553.

Ong HC. 2008. Rempah-ratus: Khasiat makanan and ubatan. Utusan Publications, Kuala Lumpur. [Malaysian]

Phongpaichit S. 2005. Antimicrobial activities of the crude methanol extract of Acorus calamus Linn. Songklanakarin J Sci Technol 27: 517-523.

Rameshkumar KB, Aravind AAP, Vinodkumar TG. 2015. Leaf essential oil composition of six Syzygium species from the Western Ghats, South India. Rec Nat Prod 9 (4): 592-596.

Saedi N, Crawford GH. 2006. Botanical briefs: ylang-ylang oil-extracts from the tree Cananga odorata. Cutis 77 (3): 149-150.

Sastrohamidjojo H. 2004. The Essential Oils Chemistry. Gadjah Mada University, Yogyakarta. [Indonesian]

Serban ES, Ionescu M, Matinca D, Maier CS, Bojita MT. 2011. Screening of the antibacterial and antifungal activity of eight volatile essential oils. Farmacia 59: 440-446.

Waranee P, Sirithunyalug J, Okonogi S. 2012. Comparison of antibacterial activity against food-borne bacteria of Alpinia galanga, Curcuma longa, and Zingiber cassumunar. Chiang Mai Univ J Nat Sci 11 (2): 177-186. 